\title{
Contextualising Pietro Monte's Military Career in Italy
}

\author{
Pascal Brioist, \\ Centre for Higher Renaissance Studies, Tours (FR), \\ pascal.brioist@univ-tours.fr
}

\begin{abstract}
Several scholars have studied Pietro del Monte's works, but only a few have focused on his military career. This article contextualises his career as a condotierre, primarily by collecting and commenting on narrative sources describing his life. From the Italian and Spanish courts where he mingled with the brightest minds of his time, to the Italian Wars where he met his death on the battlefield, Monte lived as an acting commander, a respected scholar, and a renowned master at arms.
\end{abstract}

\section{Keywords - Pietro Monte, condotierre, military career, Italy}

Long before Sydney Anglo discussed the relationship between Pietro Monte and Leonardo da Vinci in an article today well known to da Vinci specialists ${ }^{1}$, Edmondo Solmi had already spotted an allusion to Monte in the Manuscript I (French Institute). He sketched out the following portrait:

Pietro Monte, Da Giorgio, son of Ambrogio, was born in Milan in 1460. Pietro Monte was a soldier, an engineer and a theologian. As a young man he was sent to Spain and there he wrote in the local language a work full of invention and unusual comments, published later on in Milan (afterwards translated from Spanish by G. Ayora of Cordoba) in 1492, after the author came back to Lombardy, under the title De Dignoscendis hominibus (Antonius Zarotus of Parma, Milanese, printed this text in Milan in 1492 on 17 January, in round and quite neat letters, on a nice, non-paginated paper). ${ }^{2}$ One finds there pages on necromancy, physicians and principles of authority, as well as ideas in favour of experimentation; they were so much alive that they must have taken Leonardo's fancy: "Talk to Pietro Monte", writes the author about the best way to throw darts ${ }^{3}$; and this very precious annotation

\footnotetext{
1 Anglo, 'The man who taught Leonardo darts'.

${ }^{2}$ G. Ayora Cordubensis Oliverio episcopo Sabinensi Cardinalis neapolitano: pontifici illustrissimo atque amplissimo: dedication of Ayora to the cardinal Oliviero Carafa. 2. Petri Montis philosophi ad serenissimam illustrissimanque Helisabeth hispaniarum reginam benemeritam in labellum de conception virginis prefatio: interprete G.Ayora Cordubenssi. 3. Petri Monti philosophi subra virginis conceptione opusculum a G.Petrus Montis. 4 De dignoscendis hominibus. Interprete G.Ayora Cordubensi, Milano, Antonio Zarotto, 1492. Dedication by Ayora to Queen Isabel of Spain.

${ }^{3}$ Manuscript $\mathrm{H}$ fol. 94r. Pietro next to "Giacomo Andrea of Ferrara".
} 
by Leonardo da Vinci opened a very interesting path to identify one of the other great intellects who contributed to the training of one of the most famous geniuses that ever was in this world. Monte, once back at the Milanese court, gave up the art of war and philosophical abstractions, after having looked for peace of mind in conversation with friends and in theatrical shows. Convinced that nature provided him with his experience of warfare to be of help to others, he started to gather notes about this, getting closer to two masters of engineering, one practical, Galeazzo da Sanseverino, the other theoretical, Leonardo da Vinci. His De Singulari certamine exercitiorum atque artis militaris collectanea in tres libros distincta, published in Milan in 1509, was the fruit of his studies and his friendships. This very same year Monte went into the service of the Venetian Republic and acquired great fame as a tactician. He wrote the De via ad exercitia militaria. He then went into philosophical studies and, at age 42 he composed the De Unius Legis veritate et sectorum falsitate, that nobody read and where, strangely, mysticism was associated with experimentalism, and Aristotelianism was associated with new concepts proposed by da Vinci and his followers, and theology was associated with physics. ${ }^{4}$ The mystical explosions in this book are characteristic of certain pages studying the trajectory of a cannon ball thrown by a bombard in free fall, and these pages remind us of Leonardo's methods when he wrote: "Ask in which part of his curve motion the moving impetus will leave the thing moved".

This text written by Solmi inspired the later work of Valeri Malaguzzi about the court of Milan. The lines above prove that Solmi read the De Unius Legis Veritate in depth, and was not only interested in the field of mechanics but also ballistics and alchemy. Solmi was doubtless one of the first authors to have noticed that the scientific interests of Monte regarding ballistics were very close to those of Leonardo, and that the experimental attitude of both men allowed them to escape the prejudices of their time. He did not see, however, that Monte anticipated the criticism of Aristotle by Galileo regarding the acceleration of bodies in freefall (not depending of mass) by a century. These lines also prove that Solmi saw the Collectane $a^{6}$, but it is improbable that he had the opportunity to

\footnotetext{
${ }^{4}$ One unique copy of this edition of the De Unius Legis Veritate (1522) is kept in the Mazarine Library (accession number 487). Colophon: Petri Montii de Unius Legis Veritate: Et sectarum falsitate: opus excellentissimum: Perfectum fuit non parvo labore: Summaque cura revisum: \& per solertem calcographum. Io. Angelum Scinzenzeler Impressum Mediolani. Anno verbi incarnati. M.ccccxxii, Pridie Kalendas decembris.

${ }^{5}$ Solmi, Scritti Vinciani, pp. 216-7.

6 Petri Montij exercitiorum atque artis militaris collectanea In tris libros distincta. Colophon/souscription [f61(g7)] Impressum Mediolani per Joannem Angelum Scinzenzeler anno domini.M.ccccc.viiij die xxvij.Julii. [f117(g2)] PETRUS MONTJUS COMPONEBAT. [...] Impressum Mediolani.Impensa.Jo.Jacobi et fratrum de Lignano Mercatorum Mediolanensium. Anno verbi Incarnati.M.ccccix.Pridie Kalendas Septembris. Ludovico Francorum Rege.Mediolanique Duce feliciter regnante.
} 
consult the De via ad exercitia militaria, which had already disappeared in the nineteenth century. ${ }^{7}$

This work is, however, mentioned thoroughly in the prologue of the Collectanea, where Monte reports that he had worked on this synthesis of military exercises with Galeazzo de Sanseverino and Claude de Vaudrey. It can be deduced from the allusion to the Burgundian knight Pierre de Vaudrey that the collaboration on the De Via ad exercitia Militaria would date from 1495, when Sanseverino, Vaudrey, and Monte met on the occasion of a tournament in imperial territory held at the same time as the Diet of Worms. In the De unius Veritate Monte reports ballistics experiments that he would have conducted within the artillery park of Maximilian in Worms. ${ }^{8}$

If, on one hand, Solmi had a perfect knowledge of the great texts of Monte, he was seriously wrong, on the other, regarding the biographical elements of his hero. He considers Monte's birthdate to be in the 1460s, and that he was born to a Milanese family, but Marie Madeleine Fontaine proved that he was born in 1457 to Ugolino de Monte, a Tuscan marquis. ${ }^{9}$ Solmi also made a mistake when dating the death of Monte because, having consulted a 1522 version of the De Unius Legis Veritate, he deduced from it that Monte was still alive. In reality, the De Unius Legis Veritate had been originally published in 1509 and several testimonies also give evidence of the tragic end of Monte in the battle of Agnadel of the same year. ${ }^{10}$

The contextualisation of Monte's work is of such importance in my view that it is important to gather all the biographical elements that allow us to sketch out the involvement of our condottiere in the Italian Wars at the end of the fifteenth and the beginning of the sixteenth century. His reputation, built by his contemporaries and their followers, will be of much help here.

Pietro Bembo, the Venetian humanist, praised him as "a man of great courage". Francesco Sansovino, in his work on the Illustrious Families of Italy published in Venice in 1670, wrote:

It is said of Pietro that he was in his time one of the first infantrymen that Italy had. ${ }^{11}$

Gamurrini, in his Genealogical History of the Noble Families of Tuscany and Umbria, considered him "one of the most reputable of the heroes of his time, and one of the most famous captains, both because of his long experience in the trade of war and because of his tactical

\footnotetext{
7 Biographie universelle ancienne et moderne.

${ }^{8}$ Cf. De Unius Legis Veritate, chapitre LXXV. Enfin pour en revenir à la trajectoire, dans le temps où nous parcourons 16 pas ou à peine plus, le boulet sortant de la bombarde en parcourt dans les 1300. Et cela moi j'en ai fait l'expérience un jour lorsque le Roi des Romains Maximilien a fait essayer plusieurs bombardes.

${ }^{9}$ Fontaine, Le Condottiere Pietro del Monte.

${ }^{10}$ Cf. Marino Sanuto [il Giovane], Diarii, vol.XVI pp.237-9.

11 Sansovino Francesco, Origine e fatti delle famiglie illustre d'Italia.
} 
schemes". ${ }^{12}$ Sacchino described him as an "exceptional infantry captain, nobility was native in this person". 13

\section{THE BEGINNINGS OF PIETRO MONTE}

Pietro Monte showed himself to be extremely precocious in his youth. By the age of 21 he had already commanded a troop of 200 men in the service of the Florentines against the Aragonese (1478) and participated in the defence of the castle of Monteluco della Berardenga in Chianti.

It is possible, as suggested by Marie Madeleine Fontaine, that Monte had first visited Spain in 1481-82, and that he had met important people there.

In the spring he faced the Venetians in the Ferrara War. ${ }^{14}$ This war saw the Venetians face Ferrara supported by the Papal States. Ferrara contested Venetian imperialism on the Terra Firma and had started to seize the monopoly of the salt trade in the region (hence the alternative name of the Salt War). Captain Girolamo Riario and the men of the Pope took possession of the city of Forli, and Pietro Monte joined the expedition in August. In 1485 he was sent by the Florentines to control and defend the small town of Montepulciano. There he met Camillo Vitelli, a Capitano da Ventura serving the Pope.

In 1487 he took part, with his father, in the War of Sarzana (or Serzenella): a small city located on the edge of the Republic of Genoa and the Republic of Florence that controlled the Gulf of La Spezia. We learn of this experience through an author of anonymous rhymes who describes the conflict. ${ }^{15}$ Lorenzo da Medici had acquired the place by buying it in 1468 but the Genoese had reoccupied it nearly immediately. The Florentines had then tried, in 1484, to take back what they considered to be their property by building in front of it the fortress of Sarzanello, designed by the Florentine engineer Francesco di Giovanni, called "il Francione", and his colleague Luca del Caprina. The Rocca (fortress), built in the form of a triangle flanked by three massive towers, was defended by a hundred men. In March, the Genoese condottiere Gianluigi Fieschi tried to seize the stronghold using explosive mines. On 15 April, the Count of Pitigliano, Nicolo Orsini and his troops, of which Pietro Monte had became a captain, came to the aid of the besieged and the defeated Genoese were forced to withdraw to Sarzana. According to Benedetto Croce, among the non-commissioned officers who went into combat that day was a young Spanish man named Pedro Navarro, who later proved

${ }^{12}$ Il quale è stato uno de' più segnalati eroi di questa prosapia, ed uno de' più famosi e celebri Capitani dell'età sua, sì per la lunga esperienza del mestiero della guerra, come anco per le stratagemme. Gamurrini, Istoria genealogica delle famiglie nobili Toscane et Umbre, Vol. 1.

13 Sacchino: Excelso Capitan di fanterial costui di gentilezza era una fonte.

${ }^{14}$ For all those informations, see Roberto Daminani's website which offers a very useful dictionary of <http://www.condottieridiventura.it/ condotti/index.php/lettera-m>, accessed December $10,2018$.

${ }^{15}$ La guerra di Serrezzana, p. 9: "El marchese dal monte, un uom solenne, el signor Piero suo Figluolo ornato". 
himself in Naples by the use of explosive mines and then during the battle of Ravenna by using tanks against infantry. ${ }^{16}$

The following year, Pietro married Sveda Oddi, the daughter of another Condottiere native to the city of Perugia. Monte immediately lent his military knowhow to the service of his father in law who was engaged in a rivalry with a lord of the neighbourhood. The loyal son in law sent his new relative 300 riders and foot soldiers to pacify the situation. We then lose his track but in 1490 he was undoubtedly in Spain at Isabel's court where he drafted the De Dignoscendis Hominibus. ${ }^{17}$ It is a work dedicated to the infante Juan of Spain, to whom he gave advice about military training (how to prepare his body for the fight, for throwing javelins, how to know horses and men according to their temperaments etc.). Monte was on good terms with the nobility (the grand master of the Order of Calatrava, for example) and maybe took part in the conquest of Granada. ${ }^{18}$

Numerous references that can be found in the Collectanea relating to Spanish methods of fighting and to Spanish weaponry ("In Spain, they call them...") can certainly be understood within the context of Monte's time spent in Spain. Thus, his familiarity with the ways of warfare "in the jinetes manner" (the jinetes were Iberian riders who used javelins and displayed their talents at competitions called Juegos de canas) is explained by Monte's stay in Spain and experience of the wars in Granada, and maybe also even by that of his friend, the Count of Ujuena, who commanded a Jinetes company. ${ }^{19}$ Leonardo da Vinci's sentence "speak with Pietro Monte about the way of throwing darts" no doubt refers to the fact that Pietro had brought back from Spain a very exotic way of fighting.

\section{THE PISAN WAR}

In 1492 Monte was to be found in Italy, between Milan (where the De Dignoscendis Hominibus was finally published), Naples, and Rome. He was familiar with the families of condottieri, like the Sanseverino, and cardinals like Carafa. ${ }^{20}$ It is at this time that he befriended Leonardo da Vinci and Galeazzo da San Severino in Milan. In 1494, from the Aragonese camp of Lugo in Romagna, he asked the Florentines officers to pay his mercenaries. He was therefore by this time a renowned condottiere whose military experience acquired during the wars of Italy and the Iberian Reconquista was as important as his reputation.

The following years found Monte involved in the war between Florence and Pisa (then an ally of Venice). It is from accounts of this war by Guichardin that we can follow the details of the operations. ${ }^{21}$ In 1496, for example, Monte was sent to the aid of Verrucola, a fortress dominating the plain of the Arno and the Pisan hills that Pisans and Florentines

\footnotetext{
${ }^{16}$ Croce, La Spagna nella vita italiana durante la rinascenza, p.260.

${ }^{17}$ Fontaine, «Comment Pietro del Monte, condottiere italien, parlait espagnol », pp. 163-73.

18 Fontaine, Le Condottiere Pietro del Monte, p.20.

${ }^{19}$ Cf Nicholle, Granada 1492, the Reconquest of Spain, p.24.

20 Ibid., pp.12-15.

${ }^{21}$ Guicciardini, Storia d'Italia, pp.38-39.
} 
fought over. Monte failed in holding Verrucola, which was taken back by the troops of Pisa, and he withdrew his men from it. In December of the same year, he led, however, an almost victorious attack against the Pisan suburb of San Marco. The city of Pisa owed its survival to the intervention of the French garrison. In 1498 a new offensive took place under Paolo Vitelli's banner against Pisa. This time Monte commanded some 500 foot soldiers. In 1499, always in connection with captain Vitelli, Monte captured the village of Cascina, at the foot of the hills, ensuring the Florentines an important bridgehead. In October of the same year he led a military enterprise to capture Vitellozzo Vitelli, suspected of betrayal, in his own tent. Vitelli only just escaped thanks to his soldiers. The following autumn Monte launched a new offensive against the walls of Pisa, this time accompanying the Florentine officer Antonio Giacomini, but a dispute arose when the latter wanted to punish a soldier of Pietro's company for having hurt another soldier. Both officers grew angry, contesting their mutual ranks against one another. A further quarrel aggravated things even more when a French captain, named Guerrier, challenged an officer of Monte's company. Giacomini, this time, decided to punish the Frenchman but as this one threatened to leave with his troops, the authorities preferred to keep a low profile and not to offend the man of Louis XII. Monte was hurt but continued to serve the Florentine Republic.

In January 1502, for example, he organised the defence of the fortified town of Vicopisano near Verrucca, but he became ill and his successors failed to hold the town, which then fell into Pisan hands. Monte continued to harass the area around Cascina until the capture of Arezzo, occupied by Vitellozzo Vitelli (against Florence), meant that his services were no longer required. From 1501 to 1505 he diverted his attention away from Tuscany and turned to Umbria, then Romagna (against Venice), but always fighting for the Florentine Republic. He was called back to Tuscany in 1505, when the Venetian forces lead by Bartolomeo d'Alviano advanced against Pisa. There, Monte proved his stratagem and fighting techniques. Sansovino relates:

Bartolomeo Alviano, General of the King of Naples helping Pisa. Pietro went to the Tour of San Vincentio in Campiglia and took it with a few men. Having mixed his cavalry with infantry armed with guisarmes (ronca), he ordered them to wait and to free the enemy horses from their bridles. The horses, being freed from their bridles and their masters not able to control them anymore, fled against their own troops. ${ }^{22}$

One of the key reasons for the victory of the Tour of San Vicentio was the ability of a well-trained infantryman armed with a staff weapon to face a well-armed horseman. This description matches chapter 44, book II, of the Collectanea:

22 Pietro, si dice che nell'eta sua fu il primo fante a pie che havesse l'Italia, nell'acquisto di Pisa per i Fiorentini, si porto con incredibil valore. Percioche andando Bartolomeo d'Alviano Generale del Re di Napoli al soccorso di Pisa, Pietro coltolo alla Torre di San Vicentio in Campiglia, lo roppe con poca gente; conciosia che havendo collocato fra la cavaleria diversi fanti a pie con le ronche, ordino loro che attendeffero solamente a sbrigliare i cavalli nemici, $i$ quali sentendosi liberi e non potendo esser retti da loro padroni, si mettevano in fuga adando contra il loro propria. In Sansovino, Origine e fatti delle famiglie illustre d'Italia. 
When we are on foot waiting for a horseman, we should take our spear in both hands and extend it forward, such that if the spear is a little long, its point touches the ground. We should stand firmly until the horseman is forty or fifty paces away, and then we should hold our spear with only one hand, and use the other to throw a light spear, stone or some such at the horseman. And as he approaches us, we should quickly take the spear with both hands again to displace our opponent's weapon with our own, stepping to the side, and we should go to the side we have forward. When the opponent goes past, we should strike him or his horse, quickly following him, yet always remembering to avoid his weapon, whatever way he turns. If he tries to turn his horse, we should stay close to him, not allowing him to turn, and wounding him. If the horse charges at us, we should hit it in the head with our weapon, and spring to the side, always throwing two blows as we do with the pollaxe, one to strike the rider, the other to strike the horse. We can defend ourselves this way with a single sword against a horseman, although a medium jineta is better. In this combat we should never flee, except to evade sideways at the right moment, but never revealing where we intend to evade. And someone who remains on horseback can do little harm to a man on foot. But few men fighting on foot have enough spirit to fight against an opponent on horseback. Yet if we have the right attitude we can do pretty well, for even if we fall to the ground, which is the worst-case scenario, once we are there we can easily kill the opponent's horse from below with the sword, particularly if we are wearing armor and the horseman does not have a spear, since it is hard to reach the ground with short weapons. The rider, however should throw one blow or do a short thrust, then a long one, although the man on foot can always extend his weapon. And in this way, we can wait for the horsemen in any situation of terrain, as long as there are four or five paces between us. ${ }^{23}$

This is the advice of a professional, who not only theorises here about techniques of fighting but also managed to get his men to put into practice his approach to warfare. In September, Monte launched an attack against Pisa's walls with 3000 foot soldiers and powerful artillery. The attack pushed forwards to the Calcesana Gate and the Barbagiani Tower, but did not go well because the infantry refused to risk their lives. Only men in armour agreed to advance. Orsini himself was wounded by a shot from a harquebus that injured his foot. In 1507 Pietro Monte left the service of Florence's republic. Pietro Sansovino gave an account of the affair in these terms:

Of Pietro, one says that in his time, he was the first foot soldier of Italy, and in the siege of Pisa by the Florentines, he showed an incredible value ... After that he left the Florentines

\footnotetext{
${ }^{23}$ Monte, Petri Montii Exercitiorum atque artis militaris collectanea, liber II, capitulus xliiii. For the English translation, see Forgeng, Pietro Monte's Colelctanea.
} 
because he was not recognised according to his merits; and, because the latter had accused him of the escape of a prisoner, he put himself at the service of the Venetian Republic.

Perhaps, however, these psychological motivations put forward by the Venetians, weighed just as much as financial reasons. In the service of the Serenissima, Monte received an enormous salary: 300 ducats in times of peace and 600 ducats in times of war.

\section{THE FRIOUL CAMPAIGN AND THE BATTLE OF AGNADEL}

In November 1507, in the Casentino, Pietro Monte began to gather his condotta for the Venetians. In February 1508 he joined Bartolomeo d'Alviano and his Venetian militia in Friuli, heading a troop of 750 men. The Imperials, who had been allied to Louis XII since 1504, and to Pope Jules II, threatened the States of Terra Ferma (Venetian provinces) from the north. At any time, Maximilian's army could cross the mountains through the Trentino. In March, as a matter of fact, the Imperials were there, in Rio Secco, but Pietro Monte and Bartolomeo d'Alviano triumphed over these Landsknechts. Sansovino explains:

Alviano brought in 1800 infantrymen, whose captain was Pietro Monte, a man of great courage, and some two hundred light riders (stradiots) among whom were Paleologue and Busicchio Capi, as well as crossbowmen, in large number, and heavy knights of his company and a few others, there again two hundred. By a letter from Savorgnano, from the contrade site, he was warned of the number of enemies and the reasons for the war. Savorgnano was already getting closer, while on the other side progressed del Monte, waiting for the Germans at the three bridges, ready to stand against their shot. At sunrise, they deliberated in attacking the enemy. This was happening in March. But as a lot of fog was formed that night, the assault had to be put off for another day, that is to say the next day.

Pietro led the central battalion of 600 men and invented a very special scheme that Francesco Sansovino reports:

He helped wonderfully during the war of Trieste and Cadore, against the Germans and the Emperor Maximilian, whom he defeated with honour thanks to one of his military tricks. He chose a number of soldiers from among his troops and equipped them with pikes that were longer than ordinary three-foot ones, and placed them against the Germans and pushed them back, saving the place and the people who were there. ${ }^{24}$

Indeed, although Landsknechts were in the habit of using pikes that were 4 or 5 meters long, Monte simply resolved to equip his men in the same manner as the Swiss. Monte, in Milan, had had plenty of time to observe the operations of the German mercenaries serving Ludovic the Moor: he described in his Collectanea their curious way to cross their pikes in the shape of a St Andrew's cross in order to face a cavalry charge. The victory of Rio Secco allowed him to seize Pieve di Cadore's castle. In spring, having recently joined forces with the Count of Savorgnano, leading 2600 foot soldiers, he besieged the fortress

${ }^{24}$ Sansovino, Dell'origine e de'fatti delle case illustri d'Italia (ed. 1609), p. $257 \mathrm{f}$. 
of Cormons, then the fortified city of Gorizia and the castle of Amb in Slovenia. At the latter, all the estradiots, the Slavic foot soldiers and the Germans were put to the sword.

The Venetians greatly appreciated his success and received him in July with great pomp, together with Bartolomeo d'Alviano who received the title of general. In August, Pietro Monte went to Trieste with a mission to enlist 3000 men. This Friulian campaign is evoked by the diplomat Francesco Modesti in a 1521 epic offered to Claude de France. Despite his successes, Monte had no illusions about Venice's fate in the face of a coalition between France and the Empire following the creation of the Cambrai League. Sansovino transcribed a conversation that was once reported to him:

Lord Pietro dal Monte, leader of 1,500 footmen under the banner of Saint Mark, a man of great experience not only in the art of war but also in things of the world. When the Marquis Galeotto Malaspina (with whom I lived in the vicinity of Verona with his troop of infantrymen) asked him what he thought about the present war, he made this observation to him: For the occasions of war which concern the Venetian soldiers, we will lose in Lombardy against the French. And many gentlemen who will want to do their duty there will die, and I could easily be one of those. But I guess we'll be old before this war ends and the beard will grow to the middle of the chest of the young boy. And then he showed an eight-year-old child who was his son. Of this opinion are also various other gentlemen who know the things of the world, and for this opinion they offer several reasons.

As a matter of fact, in May 1509, Pietro Monte took part in the battle of Agnadel, a Lombardian village on the banks of the Adda. He was entrusted with the command of the Venetian rear guard that was then attacked by the French vanguard of Gian Giacomo Trivulzio, who was supported by artillery and by the Gascon arquebusiers. Monte then disposed his troops and asked for the support of the five pieces of Venetian artillery that arrived late. This time, Monte, despite all of his tactical knowledge, failed to keep his pikemen in front of the heavy cavalry of Louis XII charging across terrain free from any obstacles.

The balance of forces was already against the Venetians: 4000 infantrymen on their side fought against 3000 Swiss, 3000 Gascons, and 1000 knights in armour.

The chronicles of Sanuto, corresponding to a text read before the Collegio of the Republic, provide a very moving text on the last words of the condottiere:

At this very moment a large French squadron of 800 knights appeared, even though their squadron had already been trimmed into pieces by our squadron...Seeing this squadron come towards our poor infantry, in order not to abandon them, I brought them help with my 400 men 
at arms and Lord Pietro Dal Monte told me: Lord Bartolomio, it is time to despise death to obtain victory. ${ }^{25}$

Indeed, according to the testimonies, Pietro fought with leonine courage. Degli Agostini is lyrical about him:

But the good and brave Pietro Monte did so many deeds, that the fact that he and his men were killed is very beautiful, and he was all covered in blood, killing on the battlefield to his left and to his right side, or at times, like a furious wind that knocks down the plants and the trees of his plague. He slaughtered the people in this war, wounded, smashed, brought down, spurned and killed his enemies ${ }^{26}$.

Most of the Venetian captains were eventually killed. Saccochio da Spoleto, Zitolo da Perugia, and Pietro Monte were massacred alongside their soldiers. Sanudo reports that, according to the testimony of François Gonzague, Louis XII wanted to see the body of his valiant enemy, stating that he would have paid him the price of a city and recruited him if he had been alive ${ }^{27}$. Luigi Sansovino also confirms that the monarch had the Marquis buried as a hero:

Finally, he was appointed general of the infantry that took part in the battle of Ghiaradadda, under the command of Bartolomeo d'Alviano and the Count of Pitigliano. He died in this act of arms with many others, so that King Louis XII wanted to see his body and had it buried with honours. Carlo, brother of Pietro and son of Ugolino, was also an illustrious condottiere of the Florentine Republic, by which he was entrusted with sixty men of arms. ${ }^{28}$

\section{BIBLIOGRAPHY}

\section{IV.1. Primary sources}

Eugenio Gamurrini, Istoria genealogica delle famiglie nobili Toscane et Umbre, Firenzem Onofri, 1668-1685.

Francesco Sansovino, Origine e fatti delle famiglie illustre d'Italia, Venetia, Combi e La Noù, 1670.

\footnotetext{
${ }^{25}$ M. S Sanuto Il Giovane, Diarii, vol XVI, pp. 237-39.

26: Ma il bon pietro dal monte valoroso/ fa tante prove ch'el tacer è bello;/ Ed era tuto quanto sanguinoso/ uccidendo pel campo hor questo, hor quello,/ come tal hor un vento furioso/ arbori, e piante abbatte con flagello,/ cosi costui le genti in quella guerral urta, fraccassa, uccide, abbatte, atterra. From Niccolo degli Agostini, Li Successi bellici. ${ }^{27}$ Qual fu morto perché vete il re e li andò a quella volta e pocho lontan fu amazato; qual combaté da un Cesare e il re haria pagà una città el fosse stà vivo; l'haria tolto a suo soldo. From a discourse by Francesco Gonzaga, prisoner in Venice, related by Sanuto, in his Diarii.

${ }^{28}$ Luigi Sansovino, Della origine et de'fatti delle famiglie illustri d'Italia.
} 
La guerra di Serrezzana. Il lamento di Lorenzino de Medici e del Duca Alessandro, (Firenze: Stamperia del Monitore, 1862).

Marino Sanudo [il Giovane], Il Diarii. Ed. Rinaldo Fulin, Federico Stefani, Guglielmo Berchet and Nicolo Barozzi (Venezia: Visentini, 1879-1902).

Niccolo degli Agostini, Li successi bellici seguiti nella Italia dal fatto d'arme di Gieredadda, Venezia, Zoppino, 1521.

Petri Montii De unius legis veritate et sectarum falsitate opus vtilissimum \& perspicacissimum, Mediolanis 1522.

Petri Montij exercitiorum atque artis militaris collectanea In tris libros distincta, Milano, per Giovanni Angelo Scinzenzeler, impensa Giovanni Giacomo \& fratres da Legnano, 1509.

Petrus Montis, De dignoscendis hominibus. Interprete G.Ayora Cordubensi, Milano, Antonio Zarotto, 1492.

\section{IV.2. Secondary literature}

Anglo, Sydney, "The Man Who Taught Leonardo Darts: Pietro Monte and His "Lost" Fencing Book', Antiquaries Journal: Journal of the Society of Antiquaries of London, 69 (1989), 261-78.

Biographie universelle ancienne et moderne, supplementum 74 (Paris: Michaud, 1843).

Croce, Benedetto, La Spagna nella vita italiana durante la rinascenza (Bari: Laterza, 1917).

Fontaine, Marie-Madeleine, 'Comment Pietro del Monte, condottiere italien, parlait espagnol', Bibliothèque d'Humanisme et Renaissance, vol. 54, no 1 (1992), 163-73.

Fontaine, Marie-Madeleine, Le condottiere Pietro Del Monte (Paris: Editions Slatkine, 1991).

Forgeng, Jeffrey L., Pietro Monte's Collectanea: The Arms, Armour and Fighting Techniques of a Fifteenth-Century Soldier (Woodbridge: Boydell Press, 2018).

Guicciardini, Francesco, Storia d'Italia (Paris: Baudry, 1837).

Nicholle, David, Granada 1492, the Reconquest of Spain (Oxford: Osprey, 1998).

Solmi, Edmondo, Scritti vinciani (Firenze: La Voce, 1924). 